\title{
A thermally self-sustained micro-power plant with integrated micro-solid oxide fuel cells, micro-reformer and functional micro-fluidic carrier
}

\author{
Barbara Scherrer $^{\mathrm{a}, \mathrm{b}, \mathrm{c}, *}$, Anna Evans ${ }^{\mathrm{a}}$, Alejandro J. Santis-Alvarez ${ }^{\mathrm{d}}$, Bo Jiang ${ }^{\mathrm{e}, \mathrm{f}}$, \\ Julia Martynczuk $^{\mathrm{a}, \mathrm{g}}$, Henning Galinski ${ }^{\mathrm{a}, \mathrm{b}, \mathrm{h}}$, Majid Nabavi ${ }^{\mathrm{d}}$, Michel Prestat ${ }^{\mathrm{a}}$, René Tölke ${ }^{\mathrm{a}}$, \\ Anja Bieberle-Hütter ${ }^{\mathrm{a}, 1}$, Dimos Poulikakos ${ }^{\mathrm{d}}$, Paul Muralt ${ }^{\mathrm{e}}$, Philippe Niedermann ${ }^{\mathrm{i}}$, \\ Alex Dommann ${ }^{i}$, Thomas Maeder ${ }^{\mathrm{f}}$, Peter Heeb ${ }^{\mathrm{j}}$, Valentin Straessle ${ }^{\mathrm{j}}$, Claude Muller ${ }^{\mathrm{i}}$, \\ Ludwig J. Gauckler ${ }^{\mathrm{a}}$
}

${ }^{a}$ Nonmetallic Inorganic Materials, ETH Zurich, Zurich, Switzerland

${ }^{\mathrm{b}}$ Nanometallurgy, ETH Zurich, Zurich, Switzerland

${ }^{c}$ Australian Center of Microscopy and Microanalysis, University of Sydney, Sydney, Australia

${ }^{\mathrm{d}}$ Laboratory of Thermodynamics in Emerging Technologies, ETH Zurich, Zurich, Switzerland

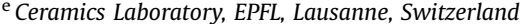

${ }^{\mathrm{f}}$ Laboratory of Microengineering for Manufacturing, EPFL, Lausanne, Switzerland

${ }^{\mathrm{g}}$ Electron Microscopy ETH Zurich (EMEZ), ETH Zurich, Zurich, Switzerland

${ }^{\mathrm{h}}$ School of Engineering and Applied Sciences, Harvard University, Cambridge, USA

${ }^{\mathrm{i}}$ Centre Suisse d'Electronique et Microtechnique, CSEM, Neuchâtel, Switzerland

${ }^{\mathrm{j}}$ Institute for Micro- and Nanotechnology, NTB, Buchs, Switzerland

\section{H I G H L I G H T S}

- The assembly and operation of a micro-power plant is successfully demonstrated.

- The micro-power plant consists of micro-SOFCs, a micro-reactor and a gas carrier.

- Above $470{ }^{\circ} \mathrm{C}$ the system run thermally independent.

- The internal reformation of butane reached a $\mathrm{H}_{2}$ yield of 60 at.\%.

- An OCV of $1.0 \mathrm{~V}$ and a maximum power density of $47 \mathrm{~mW} \mathrm{~cm} \mathrm{~cm}^{-2}$ at $565{ }^{\circ} \mathrm{C}$ were achieved.

\section{A R T I C L E I $\mathrm{N}$ F O}

\section{Article history:}

Received 19 December 2013

Received in revised form

5 February 2014

Accepted 8 February 2014

Available online 18 February 2014
G R A P H I C A L A B S T R A C T

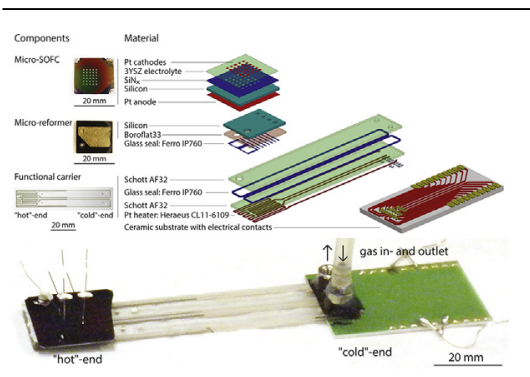

\begin{abstract}
A B S T R A C T
Low temperature micro-solid oxide fuel cell (micro-SOFC) systems are an attractive alternative power source for small-size portable electronic devices due to their high energy efficiency and density. Here, we report on a thermally self-sustainable reformer-micro-SOFC assembly. The device consists of a microreformer bonded to a silicon chip containing 30 micro-SOFC membranes and a functional glass carrier with gas channels and screen-printed heaters for start-up. Thermal independence of the device from the externally powered heater is achieved by exothermic reforming reactions above $470{ }^{\circ} \mathrm{C}$. The reforming reaction and the fuel gas flow rate of the $n$-butane/air gas mixture controls the operation temperature
\end{abstract}

\footnotetext{
* Corresponding author. Nanometallurgy, ETH Zurich, HCI G527, Vladimir-Prelog-Weg 5, 8093 Zurich, Switzerland. Tel.: +41 44632 2592; fax: +41 44 632 1101.

E-mail addresses: barbara.scherrer@mat.ethz.ch, barbara.scherrer@sydney.edu.au (B. Scherrer).

1 Current address: FOM Institute DIFFER (Dutch Institute for Fundamental Energy Research), Nieuwegein, Netherlands.
} 
Keywords:

Micro-power plant

Micro-solid oxide fuel cell

Thin films

Butane reformation

Chemical micro-reactors

Thermally independent and gas composition on the micro-SOFC membrane. In the temperature range between $505{ }^{\circ} \mathrm{C}$ and $570{ }^{\circ} \mathrm{C}$, the gas composition after the micro-reformer consists of $12 \mathrm{vol} . \%$ to $28 \mathrm{vol} . \% \mathrm{H}_{2}$. An open-circuit voltage of $1.0 \mathrm{~V}$ and maximum power density of $47 \mathrm{~mW} \mathrm{~cm}^{-2}$ at $565{ }^{\circ} \mathrm{C}$ is achieved with the on-chip produced hydrogen at the micro-SOFC membranes.

(c) 2014 Elsevier B.V. All rights reserved.

\section{Introduction}

Miniaturized fuel cell systems are an attractive alternative power source for small size electronic devices with a power range of 1-20 W. For polymer electrolyte membrane fuel cells (PEMFC) such products are already commercialized by Horizon [1] and Intelligent Energy Limited [2] and for direct methanol fuel cells (DMFC) products are announced by MTI Micro [3]. PEMFCs require pure hydrogen as a fuel gas which involves expensive external fuel reforming and storage. The drawbacks of DMFCs are the need for concentrated toxic methanol to achieve appreciable energy densities. Micro-solid oxide fuel cells (micro-SOFCs) operate at higher temperatures, and therefore, high-energy density and high specific energy hydrocarbon fuels such as propane or butane can be used. ONEBAT $^{\mathrm{TM}}$ is such a micro-SOFC system consisting of electrochemically-active micro-SOFC membranes fabricated on a micro machined chip, a gas processing unit composed of a fuel reformer, an exhaust gas post-combustor and a thermal management system and insulation [4-6]. Nectar ${ }^{\mathrm{TM}}$, a similar system based on micro-SOFC membranes is announced for commercialization, however, so far the product is not available [7]. A few patents about possible designs of an micro-power plant based on micro-SOFC membranes are available $[8,9]$.

Planar free-standing micro-SOFC membranes consisting of an YSZ electrolyte and Pt electrodes have been mostly tested [10-16]. Their power densities were measured in an external furnace or on a hot plate with pure hydrogen or hydrogen diluted with inert gases as fuel. A few publications report about anodes based on Pt, Pd or $\mathrm{Ru}$, which were tested in fuels consisting of methane or a methaneair mixture reformed in situ on the anodes [17-21]. Butane, one of the main constituents of liquefied petroleum gas (LPG), has several advantages over methane and hydrogen based fuels. At 4 bar pressure, butane is liquid at room temperature which enables easy storage and results in a higher energy density than methane. Additionally, butane is thermodynamically less stable than methane and is thus easier to reform. Takagi et al. [22] recently published tests of micro-SOFC membranes under natural gas (main constituent: methane) as fuel. They achieved a power density of $800 \mathrm{~mW} \mathrm{~cm}^{-2}$ at $530{ }^{\circ} \mathrm{C}$ with in situ reformation at the Ru anode of humidified natural gas. An in situ reforming means that the partial oxidation of the fuel happens at the anode which is thermodynamically more efficient than ex situ reformation. The direct reformation uses catalytic sites of the anode, which therefore cannot be used for the hydrogen oxidation [18] reducing the power density of the micro-SOFC. A separation of the fuel reforming and the micro-SOFC allows optimizing the reformation and should lead to a higher power density [23-25]. As the full oxidation of the fuel to $\mathrm{CO}_{2}$ and $\mathrm{H}_{2} \mathrm{O}$ leads to hot spots at the locations where the exothermic reforming reaction takes place, the resulting inhomogeneous temperature distribution at the micro-SOFC membranes lead to degradation of the anode microstructure [23]. The separation of the reforming reaction of the fuel from the micro-SOFC might overcome this drawback. Furthermore, a spatial separation of the reformer and the anode reactions potentially makes the system more flexible for the use of different fuels and the catalyst in the reformer can be adjusted accordingly independent from the anode material and thus carbon poisoning of the anode can be minimized [23]. For the partial oxidation of light hydrocarbons, $\mathrm{Ni}$, Ir, Pt, Pd and Rh on different support materials were tested as reformation catalysts [26,27]. Platinum, the most commonly used electrode material in micro-SOFC membranes, has a high tendency for dehydration and thereby forms hydroxyls which lead to carbon deposition at the Pt. Overall, Rh was identified to have the best conversion rate and the highest selectivity for $\mathrm{H}_{2}$ production among the tested catalyst materials [26]. The use of a Rh catalyst in the reformer enables Pt electrodes and still avoids cracking products at the electrode.

In this work, the results of a thermally self-sustained reformer combined micro-fuel cell assembly of the ONEBAT ${ }^{\mathrm{TM}}$ system are reported. The device was fueled with n-butane in air. With an integrated heater, the device was started until the self-sustained partial oxidation reaction of the n-butane in the micro-reformer kicks in. As reformer catalyst, 1.9 wt.\% $\mathrm{Rh}$ on $\mathrm{Zr}_{0.5} \mathrm{Ce}_{0.5} \mathrm{O}_{2}$ was used. An array of 30 individual free-standing micro-SOFC membranes consisting of a Pt-3YSZ-Pt multilayer was fabricated on a silicon chip. The performances of the micro-reformer as well as the electrochemical properties of individual micro-SOFC membranes are reported. To the authors' knowledge this is the first demonstration of such integrated micro power plant based on micro-SOFC technology.

\section{Experimental}

\subsection{Fabrication}

\subsubsection{Functional carrier}

A functional carrier (Fig. 1) was designed for gas feeding and start-up energy. It is fabricated using thick-film techniques described in detail elsewhere [28]. The functional carrier consisted of two borosilicate glass wafers (Schott AF32, Schott AG) with dimensions of $14 \mathrm{~mm} \times 75 \mathrm{~mm} \times 0.7 \mathrm{~mm}$. The Pt heaters (CL11-6109, Heraeus) were screen-printed at the bottom of the carrier and the glass walls were fabricated between two glass layers using glass frit (Ferro IP 760c, Ferro Corporation). Hermetic sealing was achieved after firing in air at $700{ }^{\circ} \mathrm{C}$ for $20 \mathrm{~min}$. This results in a cross-section of about $0.15 \mathrm{~mm} \times 5.3 \mathrm{~mm}$ of the fluidic channels. At the "cold"end of the carrier, a ceramic plate connected the heater to the startup power supply.

\subsubsection{Micro-reformer}

The planar structure of the micro-reformer (Fig. 1) allows a compact assembly design. The micro-reformer was fabricated by anodic bonding of a $1000 \mu \mathrm{m}$ thick Borofloat 33 glass to an etched $1000 \mu \mathrm{m}$ thick Si-substrate. The reactor cavity had a depth of $0.65 \mathrm{~mm}$ and a total volume of $134.8 \mathrm{~mm}^{3}$.

The 1.9 wt.\% Rh on $\mathrm{Ce}_{0.5} \mathrm{Zr}_{0.5} \mathrm{O}_{2}$ catalytic nanoparticles with an average diameter of $12 \mathrm{~nm}$ were synthesized in a one-step process by flame spray synthesis [29]. The reactor cavity was filled with a catalytic ceramic foam prepared by a one-step sol-gel process as described elsewhere [30]. In short, 15 wt.\% catalytic nanoparticles, 
a) Components

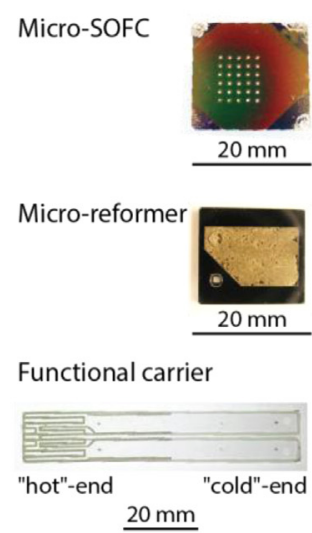

b)

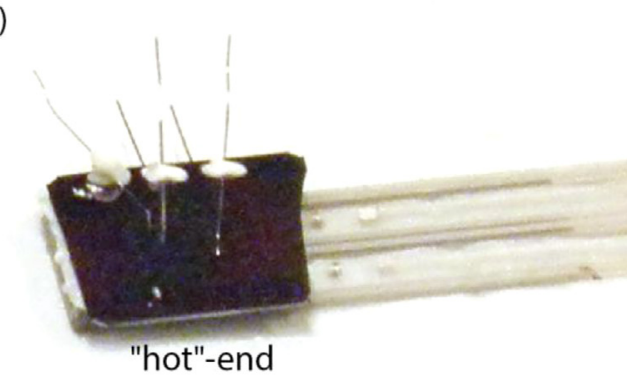

Material

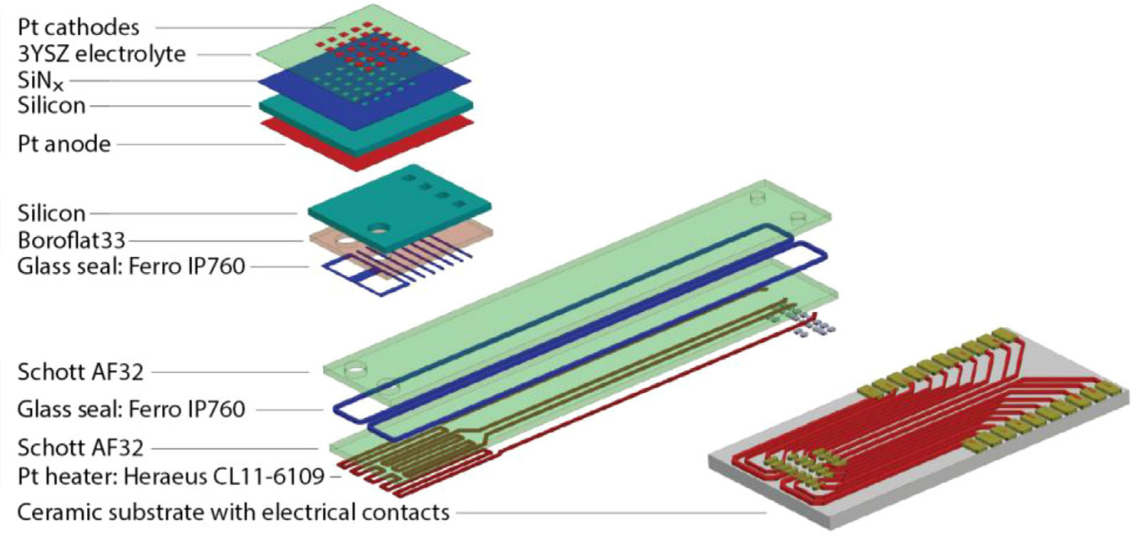

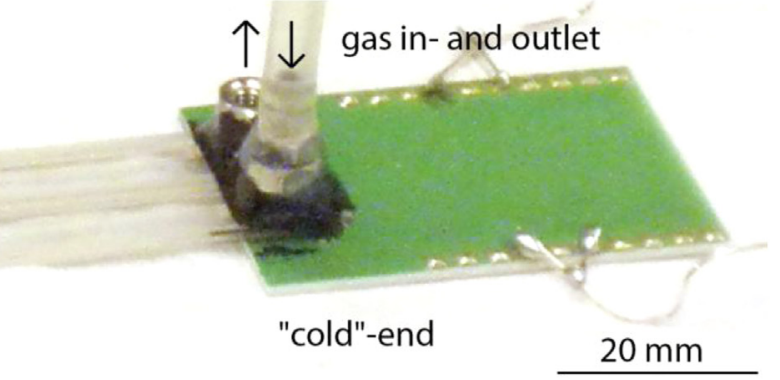

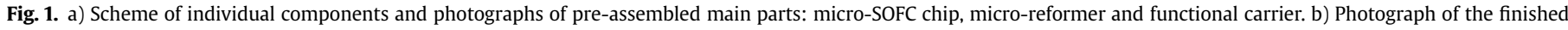
assembly. The gas inlet is already connected to the "cold"-end of the functional carrier. See Refs. [5,6,38] for further details on the single components.

80 wt.\% washed and calcined $\mathrm{SiO}_{2}$-sand (Riedel-deHaën, average diameter: $200 \mu \mathrm{m}$, puriss p.a.), 2 wt.\% gelation agent (triammonium citrate, Riedel-deHaën, purity $\geq 97 \%$ ) and 3 wt.\% ceramic binder (sodium metasilicate pentahydrate, Riedel-deHaën, purity $\geq 97 \%$ ) were mixed with the same mass of deionized water $(\rho>18 \mathrm{M} \Omega)$, stirred and placed inside of the reactor cavity. The filled reactor was dried at $100{ }^{\circ} \mathrm{C}$ for $60 \mathrm{~min}$ and heated up to $650^{\circ} \mathrm{C}$ for $20 \mathrm{~min}$ with a heating rate of $10^{\circ} \mathrm{C} \mathrm{min}^{-1}$ to ensure the stability of the catalytic bed at high temperatures.

For the catalytic partial oxidation (CPO) of n-butane (Eq. (1)), a higher mole amount is present at the reactor outlet according to thermodynamic calculations, leading to an increase in pressure drop. The design of the micro-reformer minimizes the effect of increased pressure drop along the reactor path by having a higher reactive volume towards the outlet of the reactor and at the same time a larger outlet cross-section. In this way, dead volumes are minimized.

$n-\mathrm{C}_{4} \mathrm{H}_{10}+\mathrm{O}_{2} \rightarrow 4 \mathrm{CO}+5 \mathrm{H}_{2}, \Delta \mathrm{H}_{298 \mathrm{~K}}=-316 \mathrm{~kJ} \mathrm{~mol}^{-1}$

\subsubsection{Micro-solid oxide fuel cell membranes}

Pre-etched $380 \mu \mathrm{m}$ thick silicon substrates consisting of 30 lowstress low-pressure chemical-vapor-deposited (LP-CVD) $\mathrm{SiN}_{x}$ membranes (Embedded Microsystems Bremen $\mathrm{GmbH}$ ) with dimension of $390 \mu \mathrm{m} \times 390 \mu \mathrm{m}$ were used to fabricate the microSOFC membranes (Fig. 1) [31,32]. Deposition of fully crystalline columnar $3 \mathrm{~mol} \%$ yttria-stabilized-zirconia (3YSZ) thin films on the substrate was done at $700{ }^{\circ} \mathrm{C}$ by pulsed laser deposition (PLD). The PLD target was sintered from 3YSZ powder (Tosoh Corp.) at $1400^{\circ} \mathrm{C}$ for $4 \mathrm{~h}$. The ablation was performed in a PLD workstation (SURFACE systems + technology $\mathrm{GmbH} \& \mathrm{Co}$. KG) with a KrF Excimer Laser (26000 pulses at $10 \mathrm{~Hz}$ ). The distance between the target and the substrate was $5.5 \mathrm{~cm}$. The depositions were performed at $0.27 \mathrm{~Pa}$ in an oxygen atmosphere. The deposition parameters and the electrolyte composition were chosen to optimize the micro-SOFC membrane electrical properties, microstructure and thermomechanical stability [33-35]. After the electrolyte deposition, the underlying $\mathrm{SiN}_{x}$ layer was removed by reactive ion etching (RIE 80, Oxford Instruments, Oxford). The etching was done in $50 \mathrm{sccm}$ $\mathrm{CHF}_{3}$ and $5 \mathrm{sccm} \mathrm{O}_{2}$ gas flow at $0.01 \mathrm{~Pa}$ and $100 \mathrm{~W}$ for $200 \mathrm{~s}$. Finally, Pt (purity > 99.99 at.\%, Sindlhauser Materials) was deposited onto both sides of the 3YSZ by magnetron sputtering (PVD coatings). The power was set to $100 \mathrm{~W}$ in 10 Pa with an Ar gas flow of $10 \mathrm{sccm}$. On the top side (later the cathode side), a shadow mask was used to separate the individual electrodes, whereas the bottom side (later anode side) consisted of one electrode for all micro-SOFC membranes. The Pt-load for the active membrane area was $59 \mathrm{wt} . \%$, this is calculated on the basis of non-degraded electrode thickness of $60 \pm 20 \mathrm{~nm}$ each. The electrodes were contacted via Pt paste (C3605 P, Heraeus Holding $\mathrm{GmbH}$ ) and flat-pressed Pt wires (MaTecK $\mathrm{GmbH}$ ) with a diameter of $80 \mu \mathrm{m}$ and were fixed with cement paste (TAKETSUNA Manufactory Co., Ltd.) as described in Ref. [31].

\subsubsection{Assembly}

For the assembly, a micro-reformer was glass-sealed (Ferro IP760c, Ferro Corporation) to the heated end ("hot"-end) the functional carrier. Hermetic sealing was achieved after firing in air at $700{ }^{\circ} \mathrm{C}$ for 20 min with a weight of $80 \mathrm{~g}$. The micro-SOFC chip was subsequently glued with cement paste (TAKETSUNA Manufactory Co., Ltd.) to the underlying micro-reformer (Fig. 1). The dimensions of the glass carrier and of the micro-reformer are slightly different to those reported in our earlier works [5,11,28-30,36]. They were adjusted to meet the dimensions of the chip containing the microSOFC membranes in order to avoid closing off membranes by the cement paste used for bonding. 


\subsection{Testing setup}

\subsubsection{Insulation}

For the gas composition as well as the electrochemical analysis, the assembled device was insulated up to the gas inlet and outlet with two WDS-Ultra blocks (Porextherm Dämmstoffe $\mathrm{GmbH}$ ) and Fiberfrax ${ }^{\circledR}$ ceramic paper (Unifrax Corporation). Both, gas inlet and outlet at the "cold"-end of the functional carrier, were always kept below $50{ }^{\circ} \mathrm{C}[28]$. The temperature at the "hot"-end was measured by a thermocouple touching the top of the Si-chip containing the micro-SOFC membranes.

\subsubsection{Gas composition analysis}

The CPO performance of the micro-reactor was measured by assembling a Si-chip (without micro-SOFC membranes) on top of the reformer. Catalytic partial oxidation reaction ignition was accompanied by a temperature step caused by the exothermic reaction. The step was determined by two thermocouples placed on top of the $\mathrm{Si}$ chip with an accuracy of $\pm 4{ }^{\circ} \mathrm{C}$. The operation temperature, $T_{\mathrm{op}}$, is defined as the temperature at which steady-state conditions were obtained. The effluent gas stream composition was measured by a gas chromatograph equipped with a thermal conductivity detector (6890 GC, with an HP-PlotQ column, Agilent). The molar product gas balances for $\mathrm{C}, \mathrm{H}$ and $\mathrm{O}$ atoms were reproducible within $5 \%$ for all experiments. The CPO performance was measured in terms of $n$-butane conversion, hydrogen and syngas yield as well as molar fractions of $\mathrm{H}_{2} \mathrm{O}, \mathrm{H}_{2}$ and $\mathrm{CO}$ in the outlet gas stream. The syngas yield and the hydrogen yield are defined as $\psi_{\text {syn }}=100\left(n \mathrm{H}_{2}+n \mathrm{CO}\right) / 9$ and $\Psi_{\mathrm{H}_{2}}=n \mathrm{H}_{2} /\left(5 n \times n-\mathrm{C}_{4} \mathrm{H}_{10}\right)$, respectively, where $n$ is the total amount of moles of a substance.

\subsubsection{Electrochemical characterization}

The electrochemical performance of the individual SOFC membranes was measured in the temperature regime between $400{ }^{\circ} \mathrm{C}$ and $600{ }^{\circ} \mathrm{C}$ using a stoichiometric mixture for the $\mathrm{CPO}$ reaction (10 vol.\% n-butane in air) fed to the reformer. The total inlet gas flow entering the micro-reformer was varied between $50 \mathrm{sccm}$ and $250 \mathrm{sccm}$, whereas static (laboratory) air was used at the microSOFC cathode side. Electrochemical impedance spectroscopy and current-voltage characteristics were measured by a frequency response analyser (Zahner IM6, ZAHNER-Elektrik GmbH \& Co.KG). Three individually contacted micro-SOFC membranes were measured one after the other between $500 \mathrm{mHz}$ and $4 \mathrm{MHz}$ using an oscillation amplitude of $20 \mathrm{mV}$ at open circuit voltage in air on the cathode and anode side. The current-voltage characteristics were tested under static air on the cathode side and the in situ reformed n-butane from the micro-reformer at the anode side.

The exchange current density was extracted by fitting the current response at low current densities using Eq. (2) [37].

$E(J)=E_{0}-\boldsymbol{b} \times \ln \frac{J+j_{\text {int }}}{j_{0}}-J R-\boldsymbol{m} e^{-\boldsymbol{n} J}$

In Eq. (2), $E$ is the cell voltage at the current density $J, E_{0}$ is the open circuit voltage, $j_{\text {int }}$ is the internal current density, $j_{0}$ is the exchange current density, $R$ is the ohmic resistance of the cell which was approximated by the electrolyte resistance and $\boldsymbol{b}, \boldsymbol{m}$, and $\boldsymbol{n}$ are fitting parameter. In the results and discussion section, we extract and discuss the exchange current density of the entire cell from Eq. (2). The electrolyte resistance was extrapolated using the data from the impedance measurements performed during heating in air.

\subsection{Microstructure analysis}

Top-view micrographs of the micro-SOFC thin films after testing were acquired by a scanning electron microscope (FEG-SEM, Zeiss
LEO Gemini 1530) with an in-lens detector. Transmission electron microscopy (TEM) in bright-field mode (BF) and scanning transmission electron microscopy (STEM) in high-angle annular darkfield (HAADF) mode were used to characterize the cross-sectional microstructure of the thin films after fuel cell testing. The microscope was a FEI Tecnai F-30 (field emission gun) with an accelerating voltage of $300 \mathrm{kV}$ and a post-column CCD camera. The TEM lamella was prepared by focused ion beam (FIB) etching technique on a NVision 40 (Zeiss) with a gallium liquid metal ion source, a gas injection system and a micromanipulator (MM3A, Kleindiek). After electron beam deposition of carbon, thin films were protected by a carbon cap. The TEM lamella was cut free with trenches from both sides with $13 \mathrm{nA}$ and $3 \mathrm{nA}$ at $30 \mathrm{kV}$. After the lift-out was performed, the lamella was polished to ion transparency with currents down to $10 \mathrm{pA}$ at $30 \mathrm{kV}$. Amorphization was diminished by low $\mathrm{kV}$ showering for several seconds at $5 \mathrm{kV}$ and $2 \mathrm{kV}$.

\section{Results and discussion}

In Fig. 1a), images of the prefabricated components, i.e. microSOFC, micro-reformer and functional carrier are shown on the left side. On the right side, a scheme of the assembly with the used materials is sketched. A photograph of the device prior to testing is shown in Fig. 1b). Here the gas inlet is already connected to the device. In this testing device, the "hot"-end and "cold"-end of the functional carrier are far apart to be able to connect the gas supply line directly to the device. In a commercial device, the gas tank would be integrated in the system, which will allow a much denser packaging. Several publications exist on the feasibility of entire system and possible energy sources for the start-up energy [5,6,38], here we focus only on the subsystem-micro-SOFC, micro-reformer and heater gas-supply (functional carrier).

\subsection{Gas composition analysis}

The performance of the micro-reactor was tested in a thermally self-sustained mode as described elsewhere [30]. In order to have comparable conditions for the experiments with the integrated SOFC-chip, the temperatures at steady state were targeted between $500{ }^{\circ} \mathrm{C}$ and $570{ }^{\circ} \mathrm{C}$. The total inlet flow rates were similar to those investigated with the micro-SOFC chip assembly and ranged between $150 \mathrm{sccm}$ and $190 \mathrm{sccm}$, which resulted in space times of the reactants in the catalytic bed between $15 \mathrm{~ms}$ and $21 \mathrm{~ms}$. The flow rate (amount of reactants) and therefore the space time determines the measured temperature of the reactor. The start of the CPO reaction was indicated by a sudden temperature increase caused by the released exothermic energy (Eq. (1)). The gas analysis results for the CPO of n-butane are given in Table 1. The exhaust gas was analyzed after $15-20$ min of reaction at the specified flow rate. At $190 \mathrm{sccm}$, averaged values are given for four consecutive measurements. The conversion rate of $n$-butane increases with increasing temperature; the temperature increase has a higher impact than the increase in flow rate. The reactor generates 12 at.\% to 28 at.\% of hydrogen which can be used as fuel and fed on the micro-SOFC membrane anodes. Earlier studies with the same catalyst but different geometry and flow rates showed similar hydrogen yields [10,29,30]. Pla et al. [39] reported on the design of a micro-reformer, which will convert ethanol to hydrogen, however, no performance data are published yet.

\subsection{Thermal analysis}

The device was heated up to $410^{\circ} \mathrm{C}$ by the integrated heaters of the glass carrier. During this start-up heating, a $50 \mathrm{sccm}$ air flow on the anode side and static (laboratory) air on the cathode side of the SOFC 
Table 1

CPO results at different flow rates. At $190 \mathrm{sccm}$, averaged values are shown for four consecutive measurements between $563{ }^{\circ} \mathrm{C}$ and $570{ }^{\circ} \mathrm{C}$ for a period of $95 \mathrm{~min}$.

\begin{tabular}{llll}
\hline & $\begin{array}{l}150 \mathrm{sccm} \\
\text { at } 505{ }^{\circ} \mathrm{C}\end{array}$ & $\begin{array}{l}170 \mathrm{sccm} \\
\text { at } 534{ }^{\circ} \mathrm{C}\end{array}$ & $\begin{array}{l}190 \mathrm{sccm} \text { at } \\
563{ }^{\circ} \mathrm{C}-570{ }^{\circ} \mathrm{C}\end{array}$ \\
\hline $\mathrm{C}_{4} \mathrm{H}_{10}$ conversion, at.\% & 43.1 & 51.0 & $63.2 \pm 1.7$ \\
$\mathrm{H}_{2}$ yield, at.\% & 31.9 & 44.4 & $58.5 \pm 1.8$ \\
Syngas yield, at.\% & 30.6 & 40.5 & $54.9 \pm 1.7$ \\
$\mathrm{x} \mathrm{H}_{2},-^{\mathrm{a}}$ & 12.2 & 19.2 & $28.4 \pm 0.9$ \\
$\mathrm{x} \mathrm{CO}^{\mathrm{a}}-{ }^{\mathrm{a}}$ & 8.9 & 12.4 & $19.6 \pm 0.7$ \\
$\mathrm{x} \mathrm{H}_{2} \mathrm{O},-^{\mathrm{a}}$ & 5.7 & 4.7 & $4.4 \pm 0.4$ \\
\hline
\end{tabular}

${ }^{\mathrm{a}}$ Molar fraction.

membranes was used. During this heating step in air, impedance spectra of the symmetrical membranes were recorded. The Nyquist plot consisted of two arcs: an electrolyte arc at high frequencies and an electrode arc at low frequencies. The electrolyte conductivity was calculated to be $6.9 \times 10^{-5} \mathrm{~S} \mathrm{~cm}^{-1}$ at $245^{\circ} \mathrm{C}$ and $1.9 \times 10^{-3} \mathrm{~S} \mathrm{~cm}^{-1}$ at $330^{\circ} \mathrm{C}$ which is in good agreement with literature data [35]. The $3 \mathrm{YSZ}$ conductivity also confirms that the temperature measurement on top of the Si-chip reflects the temperature of the membranes. At $410{ }^{\circ} \mathrm{C}$, 10 vol.\% of n-butane was added to the air flow. By gradually increasing the total gas flow at the anode side and decreasing the voltage applied to the heater, a self-sustained reaction was achieved at $470{ }^{\circ} \mathrm{C}$. Afterwards, the heating of the device was solely sustained by the exothermic partial oxidation of n-butane within the micro-reformer and was independent of the external power supply, which was thus switched off. The temperature was increased further by increasing the total flow rate to the reactor and therefore the anode side. Thus the operation temperature of the micro-SOFC membranes could be adjusted and controlled. Shao et al. [27] achieved in a very different set-up, namely a macroscopic, single chamber solid oxide fuel cell with a thickness of about $0.8 \mathrm{~mm}$ and reformed propane over catalytically active $10 \mu \mathrm{m}$ thick Ru-ceria layer, a similar thermally selfsustained state with internal indirect reformation; however, the start-up was done in a furnace and not like in this work with an integrated heater.

\subsection{Electrochemical analysis}

In Fig. 2a), representative current-voltage characteristics of one representative micro-SOFC membrane are shown for two temperatures. An open-circuit-voltage $(\mathrm{OCV})$ of $1.0 \mathrm{~V}$ was achieved up to a temperature of $565{ }^{\circ} \mathrm{C}$, which indicated that the sealing of the device and the $300 \mathrm{~nm}$ thick PLD 3YSZ membranes are gastight. For the generated gas mixture at $550{ }^{\circ} \mathrm{C}$, a theoretical
OCV of $1.07 \mathrm{~V}$ was calculated. This value is in good agreement with the measured values (see Supplementary Material) and is based on the individual OCVs of the electrochemically-active gas molecules $\mathrm{H}_{2}, \mathrm{CO}, \mathrm{CH}_{4}$ and $\mathrm{C}_{4} \mathrm{H}_{10}$ and their possible reactions. The second is also confirmed by the STEM analysis (Fig. 3c)). At higher temperatures, the cement paste starts to leak which results in a lower OCV of $0.6 \mathrm{~V}$ (not shown). A drastic temperature increase up to $600{ }^{\circ} \mathrm{C}$ within seconds, due to further oxidation of the fuel by the incoming air through the leakages, was then observed. All micro-SOFC membranes survived the testing procedure. This demonstrates that the free-standing 3YSZ membranes have excellent thermomechanical stability under compressive stress [32,34]. The cathode was severely agglomerated after this high temperature as shown in Fig. 3. The platinum cathode consists of isolated islands whereas the anode is still a $\sim 40 \mathrm{~nm}$ thin film and exhibits only the very first stage of coarsening. This is in contrast to findings of Kerman et al. [20] who reported faster diffusion and therefore agglomeration of platinum in hydrogen atmosphere. A similar behavior of a Pt cathode was found by Schlupp et al. [40] on free-standing aerosol-assisted CVD YSZ membranes. Their YSZ has a very similar microstructure to the PLD 3YSZ used in this study. The swifter agglomeration of the platinum cathode is ascribed to the roughness of the electrolyte whose top-side exhibits tip-shape due to the columnar growth. Below about $0.7 \mathrm{~V}$, the current-voltage $(I-V)$ curves are reproducibly unstable, even though the temperature as well as the flow rates did not change. The $I-V$ curves were measured in the potentiostatic mode only. Hanke-Rauschenbach et al. [41] call such behavior an N-shaped negative differential resistance (N-NDR) type current-voltage curve. It is highly improbable that fuel depletion caused this behavior as more than 10 vol.\% of hydrogen was generated at the reformer [42]. The high hydrogen content makes it unlikely for a competing reaction with slower kinetics, like the oxidation of $\mathrm{CO}$ or n-butane, to occur at the anode [42]. Blocking catalyticallyactive sites by another molecule with stronger adsorption to the Pt cannot be ruled out [41]. A similar behavior was observed and modeled for polymer electrolyte fuel cells and was related to condensed water of the system [43]. Even though our device runs at higher temperatures, the gas outlet is at room temperature, which could have resulted in condensation of the water in the gas outlet generated by the CPO as well as by the electrochemical reaction at the micro-SOFC anode; however, no condensed water was observed in the gas outlet after testing. Exchange current densities were calculated according to Eq. (2) [37] for the entire cell for the low-current region $(<0.7 \mathrm{~V})$ of the current-voltage curves. An exemplary fit is shown in Fig. 2a), while the exchange
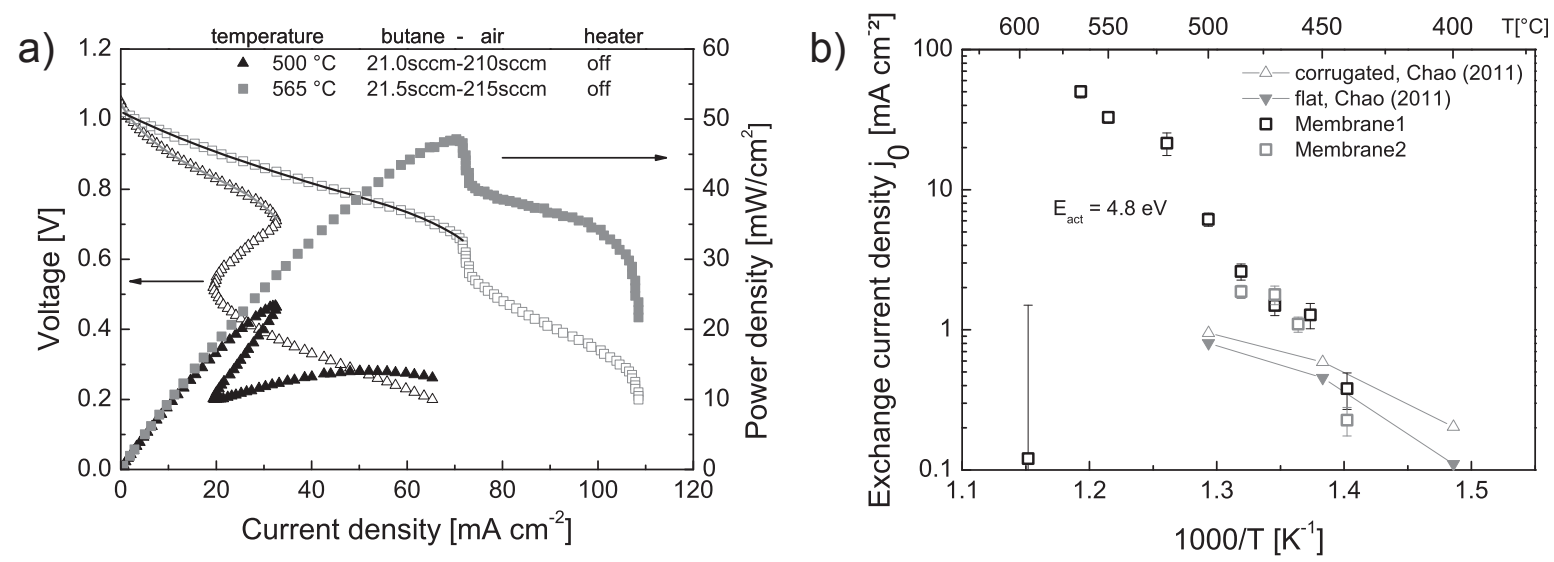

Fig. 2. a) Typical current-voltage and performance curves and b) all exchange current densities of micro-solid oxide fuel cell membranes run on in situ reformed n-butane. 


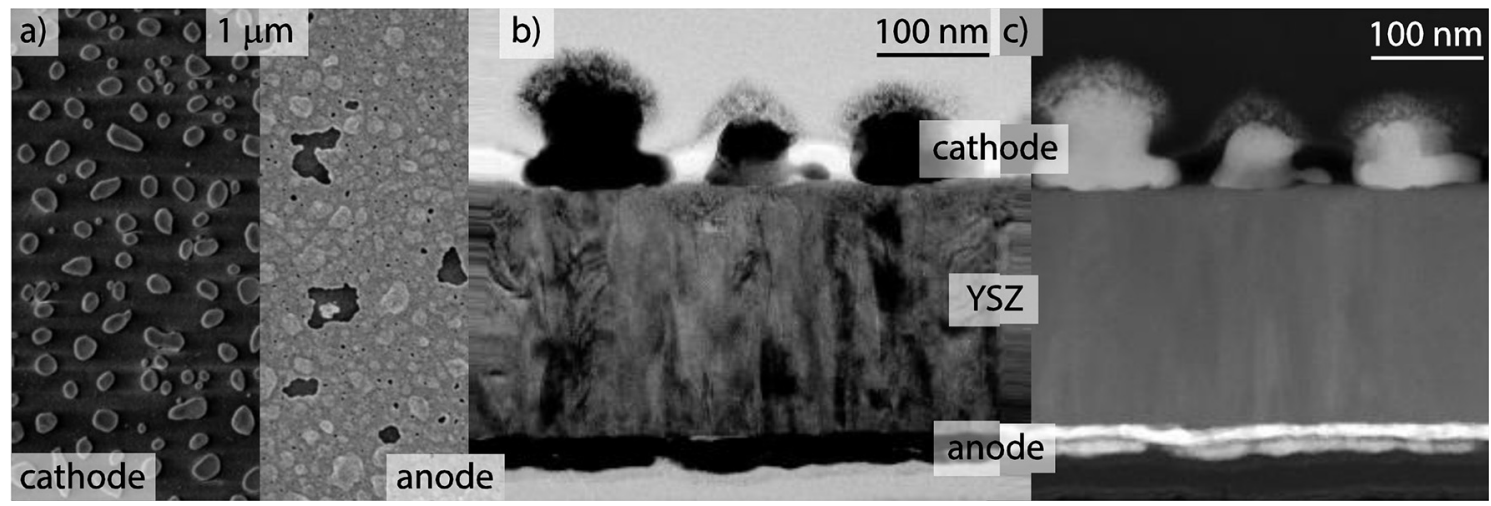

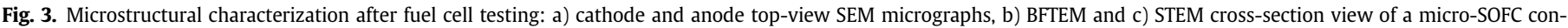

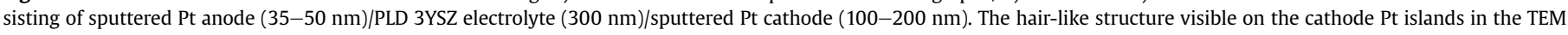
image comes from the ceramic paper used for insulation during testing.

current density plot as a function of temperature is shown in Fig. 2b). All fitting results are included in the Supplementary Material. The exchange current density of the entire cell shows a thermally activated behavior with an activation energy of $4.8 \mathrm{eV}$. The fitting value at $595{ }^{\circ} \mathrm{C}$ is not included here due to its very low OCV (discussed above). The exchange current densities are compared to the data of flat and corrugated micro-SOFC membranes measured in hydrogen fitted with the Tafel equation [11]. At temperatures of around $450{ }^{\circ} \mathrm{C}$, the exchange current densities are similar, even though the total power density measured by Chao et al. [11] is higher. At higher temperatures, the exchange current density of the entire cells measured here is almost one order of magnitude higher than the exchange current density of the nanostructured SOFC cells in Ref. [11]. The higher exchange current density but lower power density measured here are most likely due to the voltage instability found in the $I-V$-curves of the system. The high exchange current density of our membranes is a promising result for the microstructure of electrodes before agglomeration. A maximum power density of $23 \mathrm{~mW} \mathrm{~cm}{ }^{-2}$ and $47 \mathrm{~mW} \mathrm{~cm}{ }^{-2}$ at $500{ }^{\circ} \mathrm{C}$ and $565{ }^{\circ} \mathrm{C}$ were achieved, respectively (Fig. 2a)). This performance is rather low when compared to best micro-SOFC membranes performance of $1.3 \mathrm{~W} \mathrm{~cm}^{-2}$ at $500{ }^{\circ} \mathrm{C}$ [11]. Micro-SOFC operated with humidified natural gas reformed directly at the anode showed power density of $800 \mathrm{~mW} \mathrm{~cm}^{-2}$ at $530{ }^{\circ} \mathrm{C}$ [22]; however, this data was measured with an external heating source whereas the here reported power densities are achieved with self-sustained heating and on-chip reformed hydrogen which is directly fed to the micro-SOFC membranes. Considerably higher power densities are expected if more stable electrodes are used that do not show agglomeration as well as the instability is prevented $[20,44,45]$. Also different electrode materials than pure Pt are promising, whereby most of them are based on metals $[12,21,25,45,46]$ and metal-ceramic composites [17,25,27,47-49]. Pure ceramic electrodes [25,50-55] show also encouraging results. The total power density of the systems "hot"end is around $2 \mathrm{~mW} \mathrm{~cm}^{-3}$, this is calculated on the rather conservative basis of one chip with 30 membranes and a total volume of $1 \mathrm{~cm}^{3}$. Additional micro-SOFC chips would increase the total power density drastically ( $2 \mathrm{~mW}$ per chip), while only increasing the total volume by one forth per chip. The high gas flow rate of more than $150 \mathrm{sccm}$ results in poor gas utilization as well as low electrical efficiency. The high gas flow rates were used to ensure that the performance of the device is not limited by the gas supply at the micro-SOFC membrane. The performance of the reformer was tested at gas flow rates as low as $30 \mathrm{sccm}$ and it showed excellent performance [30]. The scope of this manuscript was to test and characterize the integrated system with micro-SOFC, micro-reformer and functional carrier. In future the components will be optimized for a high power generation.

\section{Conclusions}

The assembly and operation of an integrated system of microSOFC membranes, a micro-reactor and a functional carrier is successfully demonstrated in this paper. The system is operated using $n$-butane in air, which is internally partially oxidized by the Rhnanoparticle based catalytic bed in the micro-reformer. In the reformer this exothermic reaction is successfully ignited at $410{ }^{\circ} \mathrm{C}$ by an integrated heater. At temperatures higher than $470{ }^{\circ} \mathrm{C}$ the system is self-sustained. With the internal reformation, a $\mathrm{H}_{2}$ yield of up to 60 at.\% is achieved. The operation temperature is tuned by adjusting the n-butane/air flow to the reformer. An open circuit voltage of $1.0 \mathrm{~V}$ was measured at the micro-SOFC membranes. A maximum power density of $47 \mathrm{~mW} \mathrm{~cm}^{-2}$ and an exchange current density of $50 \mathrm{~mA} \mathrm{~cm}{ }^{-2}$ at $565{ }^{\circ} \mathrm{C}$ for an individual membrane are achieved. All 30 micro-SOFC membranes are still intact after testing; however, the electrodes degraded.

\section{Contributions}

B.S., A.E., A.S. and B.J. fabricated, tested and analyzed the device with the technical help of M.N., M.P., A.B., T.M. and C.M.. R.T. and P.H. helped fabricating the device. J.M. performed the TEM analysis. H.G. helped with the data analysis. B.S. wrote the manuscript with the help of A.E., A.S. and B.J.. A.B., H.G., M.P. and L.G. critically revised the manuscript. All authors discussed the results and their interpretation.

\section{Acknowledgments}

The authors thank Dr. Ji-Won Son from the Korean Institute of Science and Technology for fruitful discussions. The authors acknowledge the technical support by the FIRST cleanroom team and Electron Microscopy Center of ETH Zurich (EMEZ). B.S. and H.G. acknowledge the financial support of the "Size matters"-project, Switzerland. The financial support from the Swiss National Science Foundation (SNSF, Project No. CRSI22-126830 and grant 200021_143424) is gratefully acknowledged. L.J.G. gratefully acknowledges the support of the MEXT center of Kyushu University, Fukuoka, Japan.

\section{Appendix A. Supplementary data}

Supplementary data related to this article can be found at http:// dx.doi.org/10.1016/j.jpowsour.2014.02.039. 


\section{References}

[1] http://www.horizonfuelcell.com, 15.01.2014.

[2] http://www.beupp.com, 15.01.2014.

[3] http://www.mtimicrofuelcells.com, 15.01.2014.

[4] C. Meier, T. Hocker, A. Bieberle-Hütter, L.J. Gauckler, Int. J. Hydrogen Energy 37 (2012) 10318-10327.

[5] A. Bieberle-Hütter, D. Beckel, A. Infortuna, U.P. Muecke, J.L.M. Rupp, L.J. Gauckler, S. Rey-Mermet, P. Muralt, N.R. Bieri, N. Hotz, M.J. Stutz, D. Poulikakos, P. Heeb, P. Müller, A. Bernard, R. Gmür, T. Hocker, J. Power Sources 177 (2008) 123-130.

[6] A. Bieberle-Hutter, A.J. Santis-Alvarez, B. Jiang, P. Heeb, T. Maeder, M. Nabavi, D. Poulikakos, P. Niedermann, A. Dommann, P. Muralt, A. Bernard, L.J. Gauckler, Lab. Chip 12 (2012) 4894-4902.

[7] http://www.nectarpower.com, 15.01.2014.

[8] Roger W. Barton, Aleksander Franz, Samuel B. Schaevitz. Compact Solid Oxide Fuel Cell Apparatus, World Intellectual Property Organization, WO 2006116638 A3, PCT/US2006/016108, WO 2006116638, H01M8/02, H01M8/ 24, H01M8/12, H01M8/06, H01M8/00, WO 2006116638, 2.11.2006, 2006.

[9] Samuel B. Schaevitz, Aleksander Franz, Zachary Byars, Roger W. Barton, Systems and Methods for Stacking Fuel Cells, US20070259242 A1, 429/432, 427/ $115,429 / 509,429 / 442,429 / 469,429 / 495$, US 11/416,219, H01M8/24, H01M8/ 12, B05D5/12, 8.11.2007, US20070259242, 2007.

[10] C.-W. Kwon, J.-W. Son, J.-H. Lee, H.-M. Kim, H.-W. Lee, K.-B. Kim, Adv. Funct. Mater. 21 (2011) 1154-1159.

[11] C.-C. Chao, C.-M. Hsu, Y. Cui, F.B. Prinz, ACS Nano 5 (2011) 5692-5696.

[12] M. Tsuchiya, B.-K. Lai, S. Ramanathan, Nat. Nano. 6 (2011) 282-286.

[13] I. Garbayo, A. Tarancón, J. Santiso, F. Peiró, E. Alarcón-Lladó, A. Cavallaro, I. Gràcia, C. Cané, N. Sabaté, Solid State Ionics 181 (2010) 322-331.

[14] S. Rey-Mermet, Y. Yan, C. Sandu, G. Deng, P. Muralt, Thin Solid Films 518 (2010) 4743-4746.

[15] A. Evans, A. Bieberle-Hütter, J.L.M. Rupp, L.J. Gauckler, J. Power Sources 194 (2009) 119-129.

[16] H. Huang, M. Nakamura, P.C. Su, R. Fasching, Y. Saito, F.B. Prinz, J. Electrochem. Soc. 154 (2007) B20-B24.

[17] Y. Takagi, S. Adam, S. Ramanathan, J. Power Sources 217 (2012) 543-553.

[18] K. Kerman, B.-K. Lai, S. Ramanathan, Adv. Energy Mater. 2 (2012) 656-661.

[19] Y. Takagi, B.-K. Lai, K. Kerman, S. Ramanathan, Energy Environ. Sci. 4 (2011) 3473-3478.

[20] K. Kerman, B.-K. Lai, S. Ramanathan, J. Power Sources 196 (2011) 2608-2614.

[21] B.-K. Lai, K. Kerman, S. Ramanathan, J. Power Sources 196 (2011) 6299-6304.

[22] Y. Takagi, K. Kerman, C. Ko, S. Ramanathan, J. Power Sources 243 (2013) 1-9.

[23] D. Shekhawat, J.J. Spivey, D. Berry, Fuel Cells: Technologies for Fuel Processing, first ed., Elsevier Science, 2011.

[24] S. McIntosh, R.J. Gorte, Chem. Rev. Columbus 104 (2004) 4845-4866.

[25] M. Cimenti, J. Hill, Energies 2 (2009) 377-410.

[26] M. Huff, P.M. Torniainen, L.D. Schmidt, Catal. Today 21 (1994) 113-128.

[27] Z. Shao, S.M. Haile, J. Ahn, P.D. Ronney, Z. Zhan, S.A. Barnett, Nature 435 (2005) 795-798.

[28] B. Jiang, P. Muralt, P. Heeb, A.J. Santis-Alvarez, M. Nabavi, D. Poulikakos, P. Niedermann, T. Maeder, Sens. Actuat. B Chem. 175 (2012) 218-224.

[29] A.J. Santis-Alvarez, M. Nabavi, N. Hild, D. Poulikakos, W.J. Stark, Energy Environ. Sci. 4 (2011) 3041-3050.
[30] A.J. Santis-Alvarez, M. Nabavi, B. Jiang, T. Maeder, P. Muralt, D. Poulikakos, Chem. Eng. Sci. 84 (2012) 469-478.

[31] A. Evans, C. Benel, A.J. Darbandi, H. Hahn, J. Martynczuk, L.J. Gauckler, M. Prestat, Fuel Cells 13 (2013) 441-444.

[32] R. Tölke, L.J. Gauckler, U. Kunz, A. Krauss, M. Prestat, Fuel Cells 13 (2013) 695-702.

[33] S. Heiroth, R. Frison, J.L.M. Rupp, T. Lippert, E.J. Barthazy Meier, E. Müller Gubler, M. Döbeli, K. Conder, A. Wokaun, L.J. Gauckler, Solid State Ionics 191 (2011) 12-23.

[34] A. Evans, M. Prestat, R. Tölke, M.V.F. Schlupp, L.J. Gauckler, Y. Safa, T. Hocker, J. Courbat, D. Briand, N.F. de Rooij, D. Courty, Fuel Cells 12 (2012) 614-623.

[35] M.V.F. Schlupp, B. Scherrer, H. Ma, J.G. Grolig, J. Martynczuk, M. Prestat L.J. Gauckler, Physica Stat. Sol. A 209 (2012) 1414-1422.

[36] B. Jiang, P. Muralt, T. Maeder, P. Heeb, A.J.S. Alvarez, M. Nabavi, D. Poulikakos P. Niedermann, Procedia Eng. 25 (2011) 811-814.

[37] S.D. Fraser, V. Hacker, J. Appl. Electrochem. 38 (2008) 451-456.

[38] M.J. Stutz, R.N. Grass, S. Loher, W.J. Stark, D. Poulikakos, J. Power Sources 182 (2008) 558-564.

[39] D. Pla, M. Salleras, I. Garbayo, A. Morata, N. Sabaté, N. Jiménez, J. Llorca, A. Tarancón, in: Proceedings of the 10th European SOFC Forum, 2012, pp. B11113-B11121.

[40] M.V.F. Schlupp, A. Evans, J. Martynczuk, M. Prestat, Adv. Energy Mater. (2013) (n/a-n/a).

[41] R. Hanke-Rauschenbach, M. Mangold, K. Sundmacher, Rev. Chem. Eng. (2011) 23.

[42] W.G. Bessler, S. Gewies, C. Willich, G. Schiller, K.A. Friedrich, Fuel Cells 10 (2010) 411-418.

[43] M. Groetsch, Fakultät Elektrotechnik und Informationstechnik Otto-vonGuericke-Universität Magdeburg, 2010.

[44] T. Ryll, H. Galinski, L. Schlagenhauf, P. Elser, J.L.M. Rupp, A. Bieberle-Hutter, L.J. Gauckler, Adv. Funct. Mater. 21 (2011) 565-572.

[45] T. Ryll, H. Galinski, L. Schlagenhauf, F. Rechberger, S. Ying, L.J. Gauckler F.C.F. Mornaghini, Y. Ries, R. Spolenak, M. Döbeli, Phys. Rev. B 84 (2011) 184111.

[46] T.P. Holme, F.B. Prinz, J. Phys. Chem. C 115 (2011) 11641-11648.

[47] D. Klotz, J. Szasz, A. Weber, E. Ivers-Tiffée, ECS Trans. 45 (2012) 241-249.

[48] J. Szász, D. Klotz, H. Störmer, D. Gerthsen, E. Ivers-Tiffée, ECS Trans. 57 (2013) 1469-1478.

[49] G. Muller, R.-N. Vannier, A. Ringuede, C. Laberty-Robert, C. Sanchez, J. Mater. Chem. A 1 (2013) 10753-10761.

[50] B.-K. Lai, K. Kerman, S. Ramanathan, J. Power Sources 196 (2011) 1826-1832.

[51] F.S. Baumann, J. Maier, J. Fleig, Solid State Ionics 179 (2008) 1198-1204.

[52] J. Hayd, L. Dieterle, U. Guntow, D. Gerthsen, E. Ivers-Tiffée, J. Power Sources 196 (2011) 7263-7270.

[53] P. Plonczak, M. Søgaard, A. Bieberle-Hütter, P.V. Hendriksen, L.J. Gauckler, J. Electrochem. Soc. 159 (2012) B471-B482.

[54] H.-S. Noh, H. Lee, H.-I. Ji, H.-W. Lee, J.-H. Lee, J.-W. Son, J. Electrochem. Soc. 158 (2011) B1-B4.

[55] I. Garbayo, V. Esposito, S. Sanna, A. Morata, D. Pla, L. Fonseca, N. Sabaté, A. Tarancón, J. Power Sources 248 (2014) 1042-1049. 